\title{
Study of the "Ecofinish" finishing system to obtain a worn-effect denim
}

\section{Estudio de un sistema de acabado "Ecofinish" para conseguir un efecto desgastado del denim}

\author{
B. Hinojosa ${ }^{11}$, I. Montava ${ }^{1}$, E. Bou-Belda ${ }^{1}$, P. Díaz-García ${ }^{1}$, M. Bonet-Aracil ${ }^{1}$
}

Received: 1 April 2017

Accepted: 30 July 2017

\section{Abstract}

Textile industry is more and more concern about the necessity of using new and more respectful processes, developing new products or systems to carry out different treatments. Finishing treatments in textile industry are considered as no too safe regarding environment issues. These processes use large amounts of water that generate a big volume of wastewater and chemical products that cause harmful effects on human health. For these reasons and in light of the legislation, which tries to solve these problems, companies increased costs in terms of wastewater treatments and using new products respectful with environment and not harmful for human health. The aim of this research is verify the effectiveness of the new Ecofinish system, which have been developed by Care Applications S.L.U., used to treat denim fabric. To carry out the study we compare the conventional bath process and the new Ecofinish system in order to do corrosion finishing. To determine the quality differences in the final product, the color values of the samples were evaluated in terms of CIELAB values using UV-visible spectrophotometer. The tensile strength according to UNE EN ISO 13934-1 standard have been tested as well. This study confirms that this system achieves water savings and reduces the wastewater produced, getting a good corrosion treatment. This process can be considered as an alternative to the conventional one.

Key words: Ecofinish system, finishing, exhaustion, denim, stone-washing

1 Grupo Gestión Integral en la Industria Textil (GIITEX). Departamento de Ingeniería Textil y Papelera, Universitat Politècnica de València. Plaza Ferrándiz y Carbonell s/n, Alcoi, (Alicante). Corresponding author: e-mail: evbobel@upv.es 


\section{Resumen}

La industria textil está cada vez más concienciada sobre la necesidad de utilizar nuevos y más respetuosos procesos desarrollando nuevos productos o sistemas que lleven a cabo diferentes tratamientos. El sector de los procesos de acabado y tintura son considerados como no demasiado respetuosos para el medioambiente. Estos procesos utilizan gran cantidad de agua que genera un gran volumen de aguas residuales, además de utilizar productos tóxicos para el ser humano y para el ser humano. Por estas razones y atendiendo a la legislación que intenta solucionar estos problemas, las empresas están incrementando los costes debido al tratamiento de aguas residuales y la utilización de nuevos productos biodegradables o que no sean perjudiciales para la salud del ser humano. El objetivo del presente trabajo se centra en verificar la efectividad del nuevo sistema Ecofinish, el cual ha sido desarrollado por la empresa Care Applications S.L.U., utilizado para el tratamiento de corrosión de tejidos denim. Para llevar a cabo el estudio se comparan las muestras tratadas con el sistema de agotamiento convencional en prenda y tratadas mediante éste sistema pero con el sistema Ecofinish instalado. Con el fin de determinar las diferencias resultantes en las muestras obtenidas se estudian los parámetros colorimétricos en el espacio de color CIELAB utilizando el espectrofotómetro de UV visible. Se ha estudiado el comportamiento mecánico de las muestras realizando el ensayo de resistencia a la tracción de acuerdo a la norma UNE EN ISO 13934-1. Los resultados obtenidos confirman que el sistema Ecofinish consigue, además de ahorros considerables en el baño de tratamiento y reducir la cantidad de aguas residuales producidas, resultados similares o incluso mejores que el sistema convencional en el tratamiento de corrosión. Por lo que este sistema puede ser considerado como una alternativa al sistema de tratamiento convencional.

Palabras claves: Sistema Ecofinish, acabado, agotamiento, denim, corrosión.

\section{Introduction}

Eor decades, denim has been a widely used garment remaining always present in the fashion sector, being the fabric used for its manufacture possibly the best known by society throughout history, regardless of social level. In fact, denim are considered as an icon of fashion [1].

In order to revitalize denim items and help to maintain the success and its permanence in the market, new designs, color tones and finishes are developed year after year by the fashion industry, which presents a high economic potential [1].

One of the most used finishes is the discoloration of the color, by which a worn-design of the denim is contributed, even in some cases this finishing comes accompanied by breaks of the same one. This discoloration can be found by creating a drawing, discoloration in localized areas of the trousers or uniformly throughout the garment. 
To achieve these effects, there are several systems [2-8], such as the sandblasting, the laser system or the conventional exhaustion treatment by which the discoloration is achieved with oxidizing agents. These products tend not to be respectful with the environment therefore the wastewater has to be treated, making the final product more expensive. That is why there are many works that focus on developing new systems of color corrosion with the use of enzymes $[2,3,8]$.

In this document it is used a new treatment system for color discoloration by peroxidases, the Ecofinish developed by the company Care Applications S.L.U.

Ecofinish is a system of application of chemical products and colorants with a high ecological value, which manages to obtain new effects on garments. It is an accessory that is installed in vertical washing machines of conventional bath or garment dyeing, turning basic machines into special machines, more ecological and increasing their performance.

The device is equipped with a system that micronizes the drops of the treatment bath to dimensions similar to the mist, allowing its diffusion on the material in a controlled way. The nozzle is placed on the glass of the samples window of the vertical machines. The whole applied product is absorbed completely by the material, this implies a great saving of quantity of the product and water, since only the garments are capable of absorbing.

The products that can be nebulized by the Ecofinish system must have the following characteristics:

- Soluble or emulsifiable products in water

- Stable products when spraying

- Products with viscosity close to water.

In order to compare and evaluate the results obtained by performing the corrosion treatment on denim fabrics using the Ecofinish system, this same treatment is carried out by conventional exhaustion system, with the aim of evaluating the results obtained with Ecofinish system.

\section{Materiales y métodos}

The material to be treated is a textile with characteristics of denim fabric, defined in Table 1, previously dyed with blue sulfur dye. 
TABLE 1. CHARACTERISTICS OF THE FABRIC USED

\begin{tabular}{ccccc}
\hline \multirow{2}{*}{ Composition } & \multirow{2}{*}{ Structure } & \multicolumn{2}{c}{ Density } & \multirow{2}{*}{$\mathbf{g} / \mathbf{m}^{2}$} \\
\cline { 3 - 5 } & & Warp & Weft & \\
\hline $97 \%$ Co & Twill 3 E1 & 29,1 ends/cm & 24,6 picks $/ \mathrm{cm}$ & \\
$3 \% \mathrm{EA}$ & $\mathrm{B} \mathrm{3,1}$ & Tittle:1/17 Nm & Tittle: $1 / 50 \mathrm{Nm}$ & 320 \\
\hline
\end{tabular}

The corrosion treatment is carried out using a conventional exhaustion process of garment treatment (Figure 1) and this same process but with the new Ecofinish auxiliary system installed as shown in Figure 2.

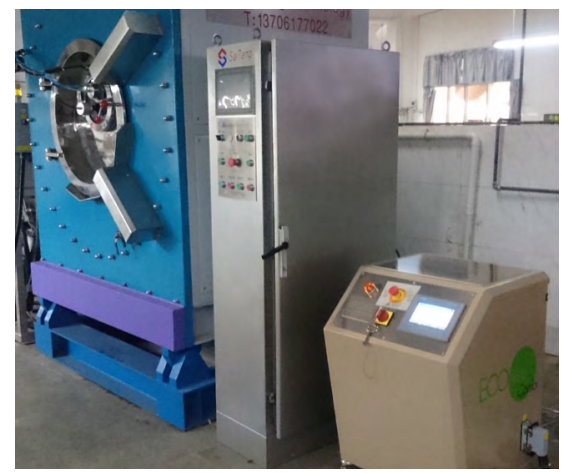

FIGURE 1. SYSTEM OF CONVENTIONAL TREATMENT ON GARMENT

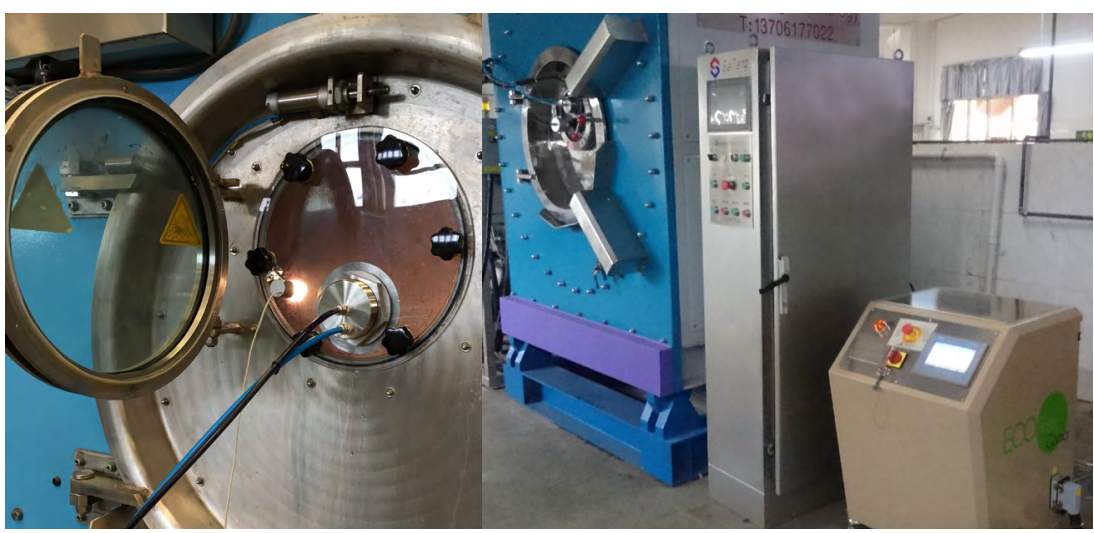

FIGURE 2. ECOFINISH SYSTEM INSTALLED IN THE SYSTEM OF EXHAUSTION IN CONVENTIONAL GARMENT

Tables 2 and 3 show the conditions used in each of the treatment systems utilized for the garment corrosion process. Two treatments are carried out in each of the processing systems, using potassium permanganate (PP) (Table 2) and peroxidases (POX) (Table 3) as corrosive agents in the application bath. 
TABLE 2. PARAMETERS OF THE CORROSION PROCESS USING POTASSIUM PERMANGANATE (PP) IN EACH TREATMENT SYSTEM.

\begin{tabular}{lcc}
\hline & Conventional system & Ecofinish System \\
\hline $\mathrm{R} / \mathrm{b}$ & $1 / 35$ & $1 / 1,5$ \\
\hline Temperature $\left({ }^{\circ} \mathrm{C}\right)$ & 35 & 35 \\
\hline Potassium permanganate $(\mathrm{PP})(\mathrm{g} / \mathrm{L})$ & 5 & 5 \\
\hline Time $(\mathrm{min})$ & 20 & 20 \\
\hline
\end{tabular}

TABLE 3. PARAMETERS OF THE CORROSION PROCESS USING PEROXIDASE (POX) IN EACH TREATMENT SYSTEM.

\begin{tabular}{lcc}
\hline & Conventional system & Ecofinish System \\
\hline $\mathrm{R} / \mathrm{b}$ & $1 / 35$ & $1 / 6$ \\
\hline Temperature $\left({ }^{\circ} \mathrm{C}\right)$ & 35 & 35 \\
\hline Peroxidases $(\mathrm{POX})(\mathrm{g} / \mathrm{L})$ & 2 & 2 \\
\hline Time $(\mathrm{min})$ & 20 & 20 \\
\hline
\end{tabular}

The corrosion process in addition to degrading the color, it may degrade the textile fibers, so in addition to analyzing the difference in color obtained after the process, the samples are characterized in order to verify that the treatment has not modified the initial physical and mechanical properties. The tests carried out for the characterization of the resulting samples are detailed below.

\section{Color Measurement}

The chromatic coordinates $\left(L^{*}, a^{*}, b^{*}\right)$ of the CIELAB color space of the treated samples were obtained with the reflectance spectrophotometer MINOLTA S.A model CM-3600d with the $10^{\circ}$ standard observer and the illuminant D65. The color difference between the treated samples and the untreated simple was obtained according to the following equation:

$$
\text { Color difference }(\Delta \mathrm{E})=\mathrm{V}\left((\Delta \mathrm{L})^{2}+(\Delta \mathrm{a})^{2}+(\Delta \mathrm{b})^{2}\right)
$$

Where $\Delta \mathrm{L}=\mathrm{L}^{*}$ untreated - $\mathrm{L}^{*}$ treated; $\Delta \mathrm{a}^{*}=\mathrm{a}^{*}$ untreated - $\mathrm{a}^{*}$ treated; $\Delta b^{*}=b^{*}$ untreated - $b^{*}$ treated; " $L *$ " describes the luminosity, "a*" measured from red-green shades, "b*" measured from blue-yellow shades. With this result, it can be objectively and numerically assessed the level of degradation caused by the treatment and compare the effect achieved using both 
processes utilized by the conventional system and this one but with the Ecofinish system installed.

\section{Tensile strength}

The mechanical properties of the fabrics may have been affected due to the corrosion agents causing in a fiber degradation that compose the fabric used in the process. This can carry a weight loss and hence, affect the physical and mechanical properties of the fabrics. In this study, the samples exposed to tensile force were examinated, under the standard UNE EN ISO 13934-1.

The dynamometer Zwick/Roell Zoo5 is used to carry out the assays, following the procedure indicated under the standard.

\section{Abrasion resistance}

This essay works under an internal protocol of the Universidad Politécnica de Valencia, Campus de Alcoy carried out through an alternative Alter abraser.

This essay is aiming to determinate the cycles resisted by an abrasion submitted fabric until it breaks, as well as the matter loss in the abrasion zone.

To perform this essay, three test specimens are prepared for the warp $40 \times 400 \mathrm{~mm}$ of each fabric to analysis. Emeryl paper IA4 P320 of $3 \mathrm{M}$ kind is used as abrasive material.

\section{Results and discussion}

The measure of the color using the color space CIELAB is the most representative characterization of the corrosion process effectiveness performed in this work, with potassium permanganate and peroxidases as corrosion agents through the conventional system and the same process with the installed Ecofinish system. In order to obtain a level value of the reached degradation, the color difference is calculated $\left(\Delta \mathrm{E}_{\mathrm{ab}}\right)$. This result is obtained from the values $\left(L^{*}, a^{*}, b^{*}\right)$ of the treated fabric in comparison with the non-treated fabric values. 
TABLE 4. CROMATIC COORDINATES AND COLOR DIFFERENCE IN THE CIELAB COLOR SPACE OF THE TREATED AND NON-TREATED SAMPLES

\begin{tabular}{lccccc}
\hline Samples & & $\mathbf{L}^{*}$ & $\mathbf{a}^{*}$ & $\mathbf{b}^{*}$ & $\mathbf{\Delta E}_{\mathrm{ab}}$ \\
\hline Non-treated & & 38,042 & $-0,6574$ & $-4,9156$ & \\
\hline Conventional & PP & 64,4185 & $-2,2563$ & $-9,3971$ & $\mathbf{2 6 , 8 0 2 2}$ \\
\cline { 2 - 6 } System & POX & 40,8053 & $-1,3755$ & $-6,8659$ & $\mathbf{3 , 4 5 7 6}$ \\
\hline Ecofinish & PP & 55,1467 & $-2,729$ & $-9,8464$ & $\mathbf{1 7 , 9 2 1 3}$ \\
\cline { 2 - 6 } System & POX & 41,2931 & $-1,3494$ & $-7,0287$ & $\mathbf{3 , 9 3 8 7}$ \\
\hline
\end{tabular}

As previously commented, the " $L$ " describes the luminance, " $a *$ " redgreen color shades measure, " $b$ *" blue-yellow color shades measure. First of all, we analyze if the sample tone is being modified with the treatment. Given that the main tone variation, corresponding to the chromaticity, and this parameter is described by the $a *$ and $b$ * values, these colorimetric coordinates are represented in the figure 3 , which form a perpendicular plane to the lightness ( $L$ ). The $a^{*}$ coordinate define the achromatic point deviation corresponding to the lightness, to the red if $a *>0$, to the green one if $a *<0$. Equivalent, the $b^{*}$ coordinate define the deviation to the yellow if $b *>0$ and to the blue one if $b^{*}<0$.

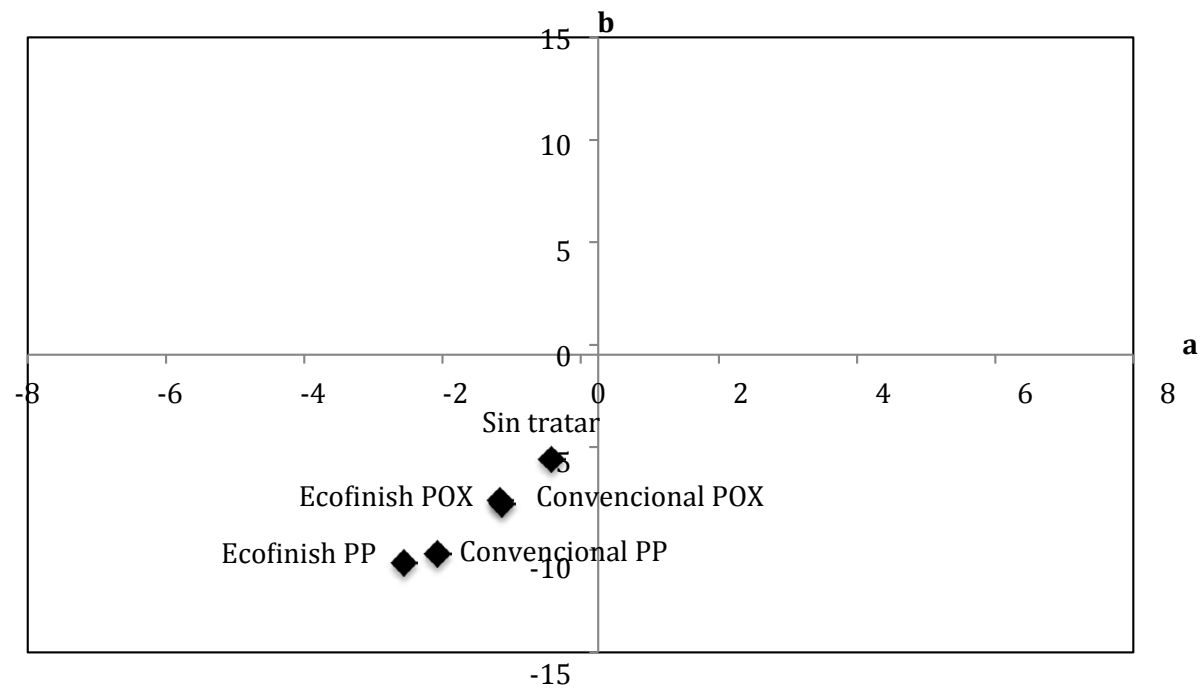

FIGURE 3. CHOMACITY DIAGRAM. COLORIMETRIC $a *$ AND b* COORDINATES REPRESENTATION TO EACH OF THE ANALYZED SAMPLES. 
According to the chromaticity diagram represented in the figure 3 , it is observed that all the samples show a greenier blue tone. If the treated samples are compared to the non-treated samples, it is observed that there is a greener tone, although the showed differences are not significant.

Given that the corrosion treatment degrades the treated sample color, the variation of $L^{*}$ of the treated samples by different process and corrosion agents is studied. The results are represented in the figure 4 .

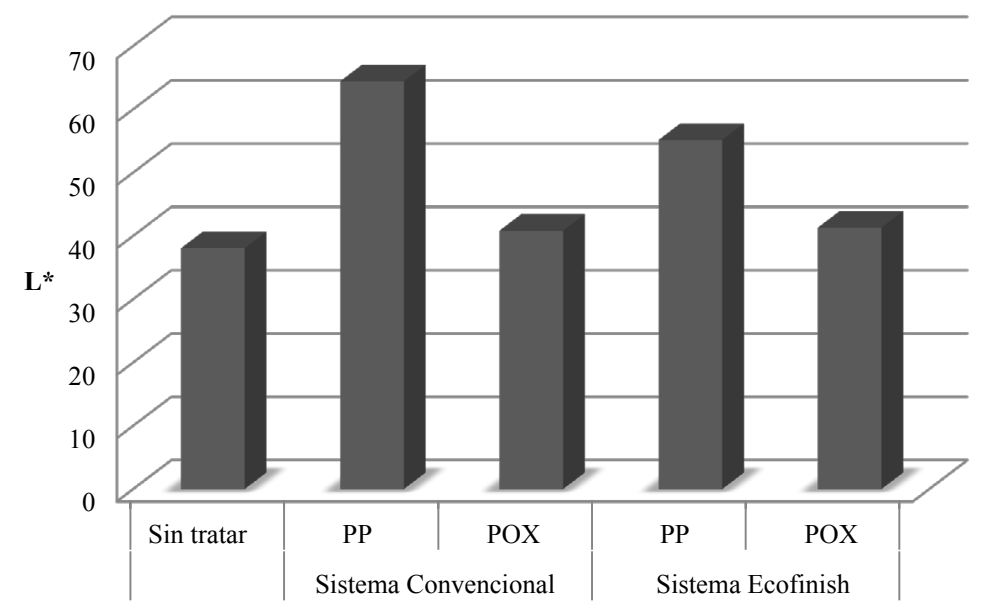

Figure 4. CHROMATICITY DIAGRAM. COLORIMETRIC $a^{*}$ AND b* COORIDNATES REPRESENTATION TO EACH OF THE ANALYZED SAMPLES.

At first glance, it is observed in the figure 4 that the $L^{*}$ value is higher in the treated fabrics than in the non-treated fabrics since lighter tones are obtained. It must be taken into account that the $L^{*}$ can range from 0 to 100 , being 100 the lighter (White) and the darker (black). The results which show a higher $L$ are those with the potassium permanganate treatment, obtaining the higher $L$ value the one that is treated through conventional exhaustion system. In contrast, when the peroxidase is used as corrosive agent, the $\mathrm{L}$ difference is not very significant in both cases, going from 38 to 40,80 when the conventional system is used, and 41,29 when the treatment is performed with the installed Ecofinish system.

Regarding the physical fabric properties modification, the samples tensile strength is tested. In the table 5 is showed the results mean of the tensile strength expressed in $\mathrm{N}$ in both ways, warp and weft, and the percentage of resistance loss after the corrosion treatment. 
TABLA 5. TENSILE STRENGHT IN N OF THE TREATED AND NON-TREATED SAMPLES

\begin{tabular}{llllll}
\hline & \multicolumn{2}{c}{ Warp } & \multicolumn{2}{c}{ Weft } \\
\hline Samples & & FH (N) & Dev. & FH (N) & Dev. \\
\hline Non-treated & & 722,10 & & 551,93 & \\
\hline Conventional & PP & 536,92 & $-25,64 \%$ & 439,82 & $-20,31 \%$ \\
\cline { 2 - 6 } System & POX & 539,76 & $-25,25 \%$ & 426,08 & $-22,80 \%$ \\
\hline Ecofinish & PP & 621,04 & $-13,99 \%$ & 448,90 & $-18,67 \%$ \\
\cline { 2 - 6 } System & POX & 665,47 & $-7,84 \%$ & 493,01 & $-10,68 \%$ \\
\hline
\end{tabular}

These same results are represented in the figures 5 and 6 , the tensile strength and the resistance loss after the treatment, respectively.

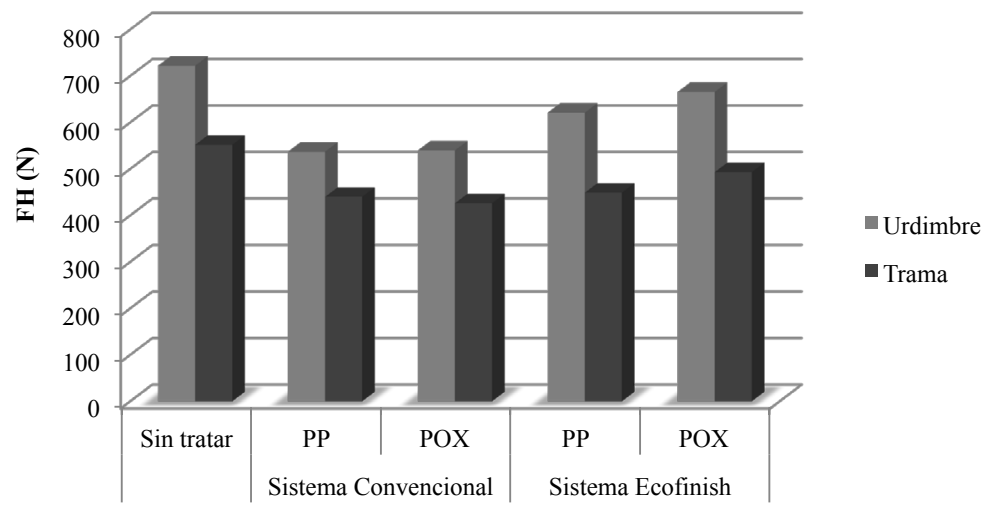

FIGURE 5. GRAPHIC REPRESENTATION OF THE TENSILE STRENGTH RESULTS OF THE TREATED AND NON-TREATED SAMPLES

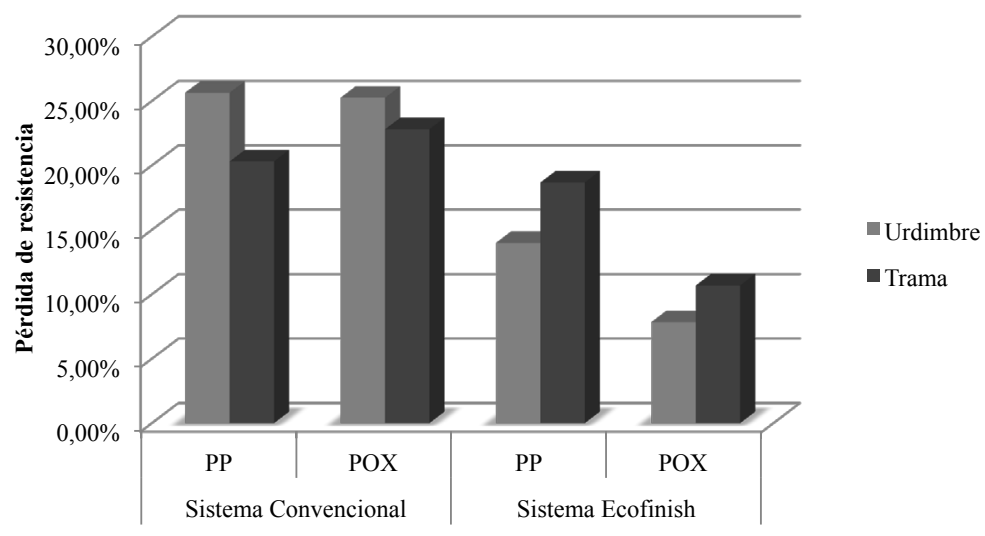

FIGURE 6. GRAPHIC REPRESENTATION OF THE RESISTANCE LOSS PERCENTAGE OF THE TREATED AND NON-TREATED SAMPLES 
All the samples get their tensile strength reduced regarding to the original fabrics in both directions, weft and warp. There's also showed a huge difference between the used treating systems, conventional and Ecofinish, being the Ecofinish treated fabric the less affected. The biggest difference that can be sighted between both systems is the POX finishing, which in the conventional system its resistance is reduced by $25,25 \%$ while with the Ecofinish just 7,84\%

The mechanical properties characterization of the denim fabrics is completed with the abrasion resistance test. The cycle mean results are presented in the following table, until the breakage of the 5 performed tests of each sample and the mass fabric loss percentage after the test, controlling the sample weight before and after the test.

TABLE 6. ABRASION RESISTANCE RESULTS OF THE TREATED AND NON-TREATED FABRICS

\begin{tabular}{lccc}
\hline Samples & & Cycle means until breakage & Mass loss \% \\
\hline Non-treated & & 196,7 & 14,6 \\
\hline Conventional & PP & 192,7 & 16,8 \\
\cline { 2 - 4 } System & POX & 201,7 & 15,4 \\
\hline Ecofinish & PP & 200,0 & 13,8 \\
\cline { 2 - 4 } System & POX & 205,7 & 13,9 \\
\hline
\end{tabular}

The abrasion resistance results show that the treatment does not modify this fabric characteristic, regardless the used corrosion agent and the employed treatment system, obtaining around 200 test cycles until the breakage in all the treated and non-treated samples. As the same way, the mass loss doesn't show significant differences ranging from 13,8 to $16,8 \%$ either.

It should be highlighted that the biggest difference between both process is the bath amount used in the treatment, because without the Ecofinish system employment, a $1 / 35$ bath proportion is used and by installing such additional system, the bath proportion decrease to $1 / 6$ and 1/1,5 when potassium permanganate and peroxidases are used respectively. In table 7 the water consumption reduction is showed, which represents the Ecofinish system employment in each of the treatments, with potassium permanganate and peroxidases as corrosion agents. 
TABLE 7. WATER CONSUMPTION IN EACH OF THE EMPLOYED PROCESS FOR THE DENIM TREATMENT

Water consumption (L) Potassium permanganate process Peroxidases process

\begin{tabular}{lcc}
\hline Conventional system & $\mathrm{R} / \mathrm{b}: 1 / 35$ & $\mathrm{R} / \mathrm{b}: 1 / 35$ \\
\hline Ecofinish & $\mathrm{R} / \mathrm{b}: 1 / 6$ & $\mathrm{R} / \mathrm{b}: 1 / 1,5$ \\
\hline Reduction & $\mathbf{8 3} \%$ & $\mathbf{9 6 \%}$ \\
\hline
\end{tabular}

The Ecofinish system represents a bath consumption application of 83 and $96 \%$ if compared with the conventional exhausting system process, which leads to a very significant water and product usage reduction.

\section{Conclusions}

The results show and verify the corrosion treatment quality and effectiveness for denim fabrics by the Ecofinish system with potassium permanganate and peroxidases enzymes. The treated samples with this system show equal or even better values than the results of the treated denim fabric through the conventional exhausting system. On the other hand, the usage of potassium permanganate or peroxidases as corrosive agents does show a clear difference, given that the obtained degradation level is higher when potassium permanganate is used, although is worth saying that if enzymes are used for treatments such as used peroxidase in this work, the process is more environmental friendly.

It is added to the Ecofinish system effectiveness for the denim fabrics treatment studied in this work, the considerable bath saving of the used treatment in the process which indeed, carries a water and needed products saving to perform the treatment. Besides, it's worth to stand out that using short bath proportions of $1 / 6$ or $1 / 1,5$, achieves the necessary quantity application that the fabric absorbs, eliminating residual waters and hence the elimination of these water treatment performed by the finishing companies and so, an important cost decrease is achieved.

\section{References}

[1] Silva, C.M., Nascimento, J.H., Miranda, T. "Art and fashion by finishing process on denim/cotton fabric", 1st International Conference on Natural Fibers Sustainable Materials for Advanced Applications, Universidade do Minho, 2013, pp. 359-360. 
[2] Heikinheimo, L., Buchert, J., Miettinen-Oinonen, A., Suominen, P. "Treating denim fabrics with Trichoderma reesei cellulases”, Textile Research Journal, 2000, 70(11), pp. 969-973.

[3] Cavaco-Paulo, A., Morgado, J., Almeida, L., Kilburn, D. "Indigo backstaining during cellulase washing”, Textile Research Journal, 1998, 68(6), pp. 398-401.

[4] Olson, L. "A new technology for stoneless stone-washing applications". Am. Dyest. Rep, 1988, 77(5), pp. 19-22.

[5] Tarhan, M., Sarışık, M. “A comparison among performance characteristics of various denim fading processes” Textile Research Journal, 2009, 79(4), pp. 301-309.

[6] Telli, A., Babaarslan, O. "The effect of recycled fibers on the washing performance of denim fabrics", The Journal of The Textile Institute, 2016, pp. 1-9.

[7] Kan, C. W., Cheung, H. F., Chan, Q. "A study of plasma-induced ozone treatment on the colour fading of dyed cotton”, Journal of Cleaner Production, 2016, 112, pp. 3514-3524.

[8] Iracheta-Cárdenas, M. M., Rocha-Peña, M. A., Galán-Wong, L. J., Arévalo-Niño, K., Tovar-Herrera, O. "Pycnoporus sanguineus laccase for denim bleaching and its comparison with an enzymatic commercial formulation" Journal of environmental management, 2016, 177, pp. 93-100. 